\title{
MOSCOW CONFERENCES ON BALKAN STUDIES
}

\section{Irina Sedakova}

Since 1990, the Institute for Slavic Studies (Russian Academy of Sciences, Moscow) has organized biennial linguo-cultural conferences on the Balkan area, covering Bulgaria, Macedonia, Serbia (and some other countries of former Yugoslavia), Greece, Romania, Albania and part of Turkey ${ }^{1}$. Slavic and Baltic studies are sometimes included in the agenda, which immensely broadens the research area and the comparative resources. I will review the topics and the academic problems discussed during the conferences and the publications prepared before (Balkanskie chteniia 1-11) and after (Obraz mira 1993; Znaki Balkan 1994; Simvolicheskii 1994; Vremia v prostranstve Balkan 1994; Slavianskoe 1977; Vostok $i$ Zapad: 2007) ${ }^{2}$ the academic meetings.

The Balkan conferences and corresponding books focus on languages, folklore and rituals of the region. Problems of the archaic Weltanschauung, folk axiology, etc. are being studied within the semiotic methodology and are discovered not only in the mentioned languages, ethnological and folklore data, but also in history, visual arts, literary works, etc. Many of the ideas initially discussed during the Balkan conferences developed into serious monographs, and were also used in the volumes of the fundamental ethno-linguistic dictionary on Slavic antiquities (Slavianskie drevnosti 1995-2009).

The very idea of such academic gatherings, uniting specialists in ancient studies to discuss the problems of the Balkan Linguistic League, mythology, folklore, material culture, literature and arts of the Balkans, was verbalized by the founders of the Moscow semiotic circle ( $I z$ rabot Moskovskogo semioticheskogo kruga: 1997) Viacheslav Ivanov, Vladimir Toporov, Tatiana Nikolaeva and Tatiana Tsivian, who were close colleagues with Mikhail Lotman and the semiotic school of Tartu.

The research ground for the modern conferences was laid during the first Balkan symposia in the early 1970s (Pervyi simpozium 1972; Balcano-BaltoSlavica 1979; Struktura teksta-81 1981), the scope of the problems for further 
discussions was clarified at the very first academic meeting (Pervyi simpozium 1972: 3). The first conferences and publications (to mention some of them: Balkany 1986; Slavianskoe 1977; Balcanica 1979; Paleobalkanistika 1989) have broadened the initial tasks and moved towards the studies of the Balkan model of the world through linguistics and structure of the text.

The 1st and 2nd Balkan conferences $(1990,1992)$ did not have a title and were dedicated to the general problems of the text structure. Starting from the 3rd Balkan Conference, a particular problem was chosen to be considered during the sessions. Thus the 3rd Balkan Conference (1994) was an arena for discussing the linguo-ethno-cultural history of the Balkans. The 4th conference (1997) concentrated on Greece and Greek language, literature and folk culture. The main theme for the 5th Balkan Conference (1999) was In Search for Balkanisms in the Balkans, addressing the core question of and the grounds for the very notion of the Balkan linguistic and ethnocultural league.

The 6th Balkan Conference was titled HOMO BALCANICUS: Behavioral Scenario and Cultural Roles. The subject matter of the 7th Balkan Conference (2003), In Search for Oriental Issues in the Balkans, and that of the 8th conference (2005), In Search for the Western Issues in the Balkans, attracted a number of scholars as the questions of interference and influence are very significant for the multilingual and multicultural Balkans.

The 9th Balkan Conference (2007) was dedicated to the jubilee of the distinguished balkanist Tatiana Tsivian. The festschrift, Terra Balcanica. Terra Slavica, was published for that occasion and comprised the presentations of the conference as well as other articles in honor of the scholar (Balkanskie chteniia 9). The 10th Balkan Conference was dedicated to another important date centenary of the publication of A. van Gennep's book Rites de Passage, which turned into a classic handbook for the ethnologists and culturologists. The topic of the conference, Transitions. Transit. Transformations, appealed to those who are interested in the development of the concept of transition and its stages in the languages, folklore pieces and rituals in the Balkans from ancient times up until today (Balkanskie chteniia 10).

The 11th Balkan conference, Balkan Spectrum: from Light to Color, took place at the institute on March 22-24, 2011. The book of preliminary materials with 40 papers was published prior to the conference which was indeed an international event - with presentations delivered by 15 scholars from 9 countries. Joseph Brian (USA) discussed the problems concerning the sound symbolism of words denoting "light and fire" in Albanian and Greek languages. Symbols related to the color of the skin, as a marker of beautiful (our own, familiar) and ugly (somebody else's, unknown) persons in Balkan folklore was 
the subject matter raised by Victor Friedman (USA). General symbolic features of the Slovenian folklore spectrum were reviewed by Zmago Šmitek (Slovenia). The Balkan Slavic specific of the color semantics in the Slavic traditional cultures was revealed by Olga Belova (Russia). Anton Tunin (Russia) shed light on the role of color in modern Greek riddles, and classified color epithets according to their pragmatics.

The archaic color triangle "white-red-black" (determined by Victor Turner) proved to be in the core of Balkan traditional culture, as Denis Ermolin (Russia), Agata Iakimova (Russia), Aleksander Novik (Russia) showed in their papers on funeral rites and national costumes in the Balkan countries. The opposites - white and black - in various contexts can develop ambivalent connotations and even turn into synonyms in folk beliefs, as Irina Sedakova (Russia) showed in her essay on the Macedonian prose of magic realism. The red color amplifies the essence of life, being connected to the color of blood, as Ljubinko Radenkovic (Serbia) and Natalia Golant (Russia) showed. Anna Plotnikova discussed different colors of the caul of a baby which predict the demonic qualities for the newly born. These beliefs are prevalent only in the western part of the Balkans which can be explained by the Roman substrate.

Light in the Balkan folk culture is perceived as one of the forms of a soul, so the demonic lights which move in the dark and are described as spirits are connected with the ideas of the cult of the dead and the other world (Mirjam Mencej, Slovenia; LudmilaVinogradova, Russia).

Ethnobotanics, which is quickly developing nowadays in Russia, added some new perspectives to the investigations of light and color in the Balkans. Aleksandra Ippolitova (Russia) compared the pictures of plants with their description in the medieval herbals, showing the conventionality between the picture and the color in the definition. Valeria Kolosova (Russia) studied the herbal terminology with the idea of fire and showed that in a phytonym various aspects of the concept of fire can be reflected: the light, bright color, or the bitter taste (*gor-) of the plant, etc.

Discussion during the conferences touched upon many other characteristics and features of the light and color: the history of the terms, the phenomenon of the fashion, the "pure linguistic" and metaphoric development of the concepts, etc.

Besides the biennial Balkan conferences, the Center for Linguo-cultural Studies organizes round tables on various fragments of the Balkan cultures. The first one, held in 2008, was dedicated to the calendric rituals, folklore and mythology regarding the month of March, and was titled Мартеница. Мărțişor 
$M \alpha \rho \tau^{\prime} \varsigma$.Verore.... The proceedings of this round table were published in a separate edition (Martenitsa 2009). Martenitsa, an artifact made of white and red yarn, is used as a gift on the 1st of March in many Balkan countries. The modern development of traditional customs, and the celebration of the 1st of March as well, shows the growth of commercialism, ornamentality and the lust for entertainment. The rituals of the 1st of March are only a small part of other calendric festivities in the Balkans. March itself is a mythological hero, who is ambivalent and can be depicted as an old woman or a man with a wild temper.

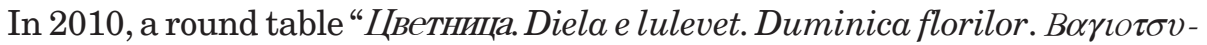
$\rho \iota \alpha \tau \sigma \eta$... Vegetative code of Palm Sunday in the Balkan-Baltic-Slavic area" was organized to discuss the terminology of the feast, the scope of the plants used in and outside the church, and the development of relevant magical practices and beliefs. The proceedings were published in 2010, in vol. 6 of the journal of traditional culture Traditsionnaia kul'tura.

\section{NOTES}

1 In 2008 the Center for Linguo-cultural Studies, BALCANICA, was established in the Institute for Slavic Studies (Russian Academy of Sciences). Before that, Balkan Studies were dealt with in many departments of the Institute and the Balkan conferences were regularly held, see (www.inslav.ru).

${ }^{2}$ A detailed review of the folklore related problems discussed during the 1st-8th Balkan conferences, and the list of papers delivered, see in Sedakova 2006.

\section{REFERENCES}

Balcanica 1979 = Balcanica. Lingvisticheskie issledovaniia 1979. Moscow: Nauka.

Balcano - Balto - Slavica = Balcano - Balto - Slavica. Simpozium. Predvaritel'nye materialy $i$ tezisy 1979. Moscow: ISB AN SSSR.

Balkanskie chteniia 1. Simpozium po strukture teksta. Tezisy i materialy. 1990. Moscow: Institut slavianovedeniia i balkanistiki (hereinafter ISB) AN SSSR.

Balkanskie chteniia 2. Simpozium po strukture teksta. Tezisy i materialy 1992. Moscow: ISB AN SSSR.

Balkanskie chteniia 3. Lingvo-etnokul'turnaia istoriia Balkan i Vostochnoi Evropy. Tezisy i materialy simpoziuma 1994. Moscow: ISB AN SSSR. 


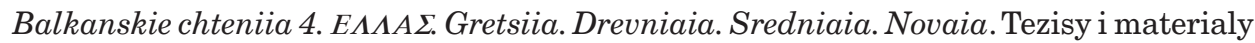
simpoziuma 1997. Moscow: ISB AN SSSR.

Balkanskie chteniia 5. V poiskakh “balkanskogo' na Balkanakh. Tezisy i materialy. 1999. Moscow: Institut slavianovdeniia (hereinafter ISl) RAN.

Balkanskie chteniia 6. Homo Balcanicus. Povedencheskie stsenarii i kul'turnye roli. Antichnost'. Srednevekov'e. Novoe vremia. Tezisy i materialy. 2001. Moscow: ISI RAN.

Balkanskie chteniia 7. V poiskakh “vostochnogo' na Balkanakh. Tezisy i materialy. 2003. Moscow: ISl RAN.

Balkanskie chteniia 8. V poiskakh “zapadnogo' na Balkanakh. Predvaritel'nye materialy. 2005. Moscow: ISL RAN.

Balkanskie chteniia 9. Terra Slavica. Terra Balkanica. K iubileiu Tat'iany Vladimirovny Tsiv'ian. 2007. Moscow: ISl RAN.

Balkanskie chteniia 10. Perekhody. Peremeny. Prevrashcheniia. Tezisy i materialy. 2009. Moscow: ISl RAN.

Balkanskskie chteniia 11. Balkanskii spektr: ot sveta k tsvetu. 2011. Moscow: Probel.

Balkany 1986 = Balkany $v$ kontekste Sredizemnomor'ia. Problemy rekonstruktsii iazyka $i$ kul'tury. Tezisy i predvaritel'nye materialy k simpoziumu 1986. Moscow: ISB AN SSSR.

Iz rabot Moskovskogo semioticheskogo kruga 1997. Moscow: Iazyki russkoi kul'tury.

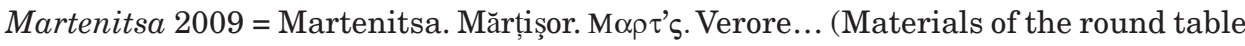
of March 25, 2008). Edited by I. A. Sedakova (ed.-in-chief) \& T. V.Tsivian \& M. M Makartsev. Moscow: ISl RAN.

Obraz mira 1993 = Obraz mira v slove i ritual. Balkanskie chteniia 1 1993. Moscow: ISB AN SSSR.

Paleobalkanistika 1989 = Paleobalkanistika $i$ antichnost'. 1989. Moscow: Nauka.

Pervyi simpozium 1972 = Pervyi simpozium po balkanskomu iazykoznaniiu. Antichnaia balkanistika (23-24 maia 1972). Predvaritel'nye materialy (Tezisy dokladov. Soobshcheniia. Annotatsii) 1972. Moscow: ISB AN SSS.

Sedakova, Irina A. 2006. Balkanskite cheteniia v Instituta po slavianoznanie pri RAN. B”lgarski folklor. Fokloristika v Rusiia, No. 3-4. Sofia, pp. 115-122.

Simvolicheskii 1994 = Simvolicheskii iazyk traditsionnoi narodnoi kul'tury. Balkanskie chteniia 2. Moscow: ISB AN SSSR.

Slavianskie drevnosti 1995 = Slavianskie drevnosti. Etnolingvisticheskii slovar' 1995 . Edited by N. I. Tolstoi. Vol. 1. Moscow: Mezhdunarodnye otnosheniia. (Vol. 2 1999; Vol. 3 - 2004; Vol. 4 - 2009).

Slavianskoe 1977 = Slavianskoe $i$ balkanskoe iazykoznanie. Karpato-vostochnoslavianskie paralleli. Struktura balkanskogo teksta 1977. Moscow: Nauka.

Struktura teksta-81 = Struktura teksta-81. Tezisy simpoziuma 1981. Moscow: ISB AB SSSR.

Vostok i Zapad v balkanskoi kartine mira: Pamiati Vladimira Nikolaevicha Toporova 2007. Moscow: Indrik. 
Vremia v prostranstve Balkan. Svidetel'stva iazyka 1994. Moscow: ISB AN SSSR.

Slavianskoe i balkanskoe iazykoznanie. Chelovek v prostranstve Balkan. Povedencheskie stsenarii i kul'turnye roli 2003. Moscow: Indrik.

Znaki Balkan. Balkanskie chteniia 2. Vols. 1-2. 1994. Moscow: Radiks. 